Donato di Paola, Mara

\title{
Belgium as a cultural model for building the Italian secondary school and
} training its teachers (1860-1900)

Casale, Rita [Hrsg.]; Windheuser, Jeannette [Hrsg.]; Ferrari, Monica [Hrsg.]; Morandi, Matteo [Hrsg.]: Kulturen der Lehrerbildung in der Sekundarstufe in Italien und Deutschland. Nationale Formate und 'cross culture'. Bad Heilbrunn : Verlag Julius Klinkhardt 2021, S. 64-82. - (Historische Bildungsforschung)

\section{Quellenangabe/ Reference:}

Donato di Paola, Mara: Belgium as a cultural model for building the Italian secondary school and training its teachers (1860-1900) - In: Casale, Rita [Hrsg.]; Windheuser, Jeannette [Hrsg.]; Ferrari, Monica [Hrsg.]; Morandi, Matteo [Hrsg.]: Kulturen der Lehrerbildung in der Sekundarstufe in Italien und Deutschland. Nationale Formate und 'cross culture'. Bad Heilbrunn : Verlag Julius Klinkhardt 2021, S. 64-82 - URN: urn:nbn:de:0111-pedocs-225785 - DOI: 10.25656/01:22578

https://nbn-resolving.org/urn:nbn:de:0111-pedocs-225785

https://doi.org/10.25656/01:22578

in Kooperation mit / in cooperation with:

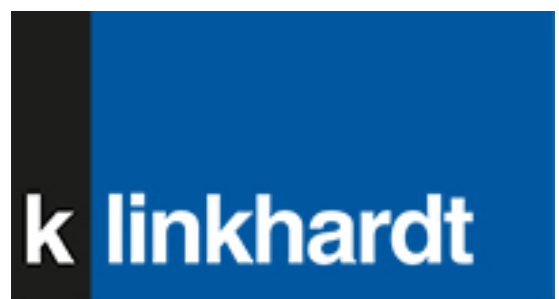

http://www.klinkhardt.de

\section{Nutzungsbedingungen}

Dieses Dokument steht unter folgender Creative Commons-Lizenz: http://creativecommons.org/licenses/by-nc-nd/4.0/deed.de - Sie dürfen das Werk bzw. den Inhalt unter folgenden Bedingungen vervielfältigen, verbreiten und öffentlich zugänglich machen: Sie müssen den Namen des Autors/Rechteinhabers in der von ihm festgelegten Weise nennen. Dieses Werk bzw. dieser Inhalt darf nicht für kommerzielle Zwecke verwendet werden und es darf nicht bearbeitet, abgewandelt oder in anderer Weise verändert werden.

Mit der Verwendung dieses Dokuments erkennen Sie die Nutzungsbedingungen an.

\section{Terms of use}

This document is published under following Creative Commons-License: http://creativecommons.org/licenses/by-nc-nd/4.0/deed.en - You may copy, distribute and transmit, adapt or exhibit the work in the public as long as you attribute the work in the manner specified by the author or licensor. You are not allowed to make commercial use of the work or its contents. You are not allowed to alter, transform, or change this work in any other way.

By using this particular document, you accept the above-stated conditions of use.

\section{Kontakt / Contact:}

\section{peDOCS}

DIPF | Leibniz-Institut für Bildungsforschung und Bildungsinformation Informationszentrum (IZ) Bildung

E-Mail: pedocs@dipf.de

Internet: www.pedocs.de

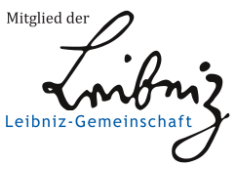




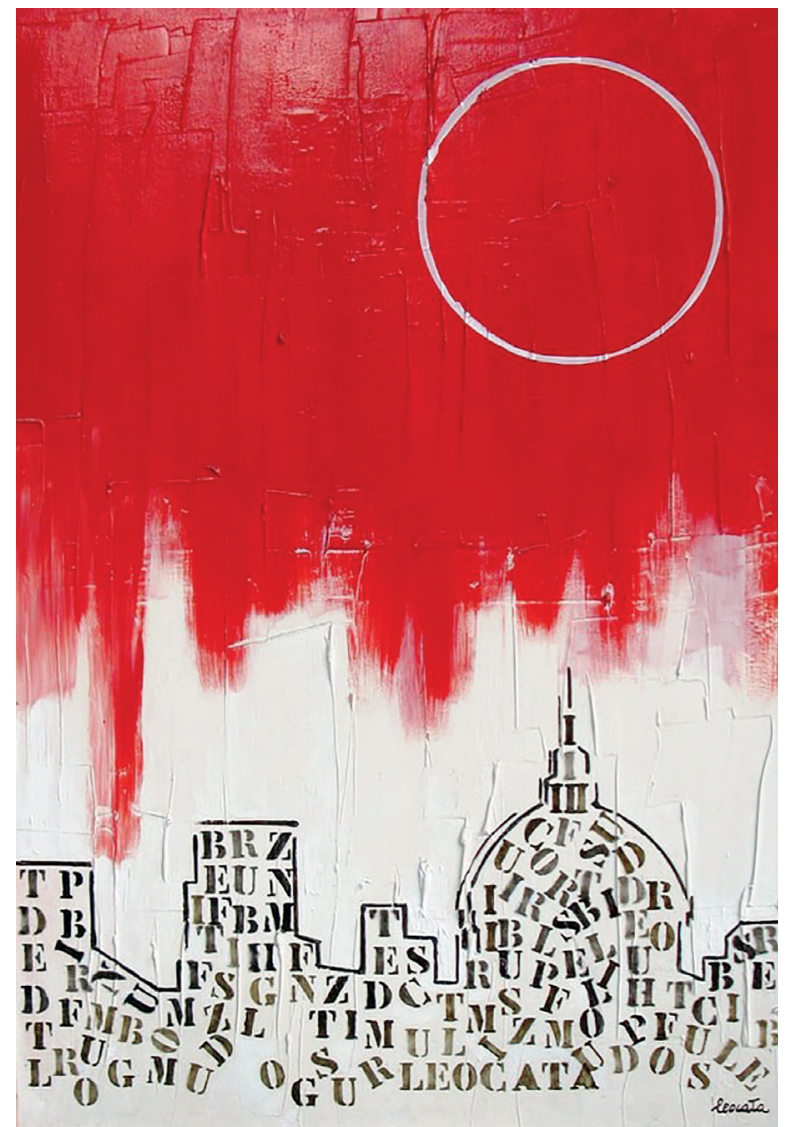

Rita Casale / Jeannette Windheuser Monica Ferrari / Matteo Morandi (Hrsg.)

\section{Kulturen der Lehrerbildung in der Sekundarstufe in Italien und Deutschland}

Nationale Formate und ,cross culture، 
Casale / Windheuser / Ferrari / Morandi

Kulturen der Lehrerbildung in der Sekundarstufe in Italien und Deutschland 


\section{Historische Bildungsforschung}

herausgegeben von

Rita Casale, Ingrid Lohmann und Eva Matthes

\section{In dieser Reihe sind erschienen}

Vogt, Michaela: Professionswissen über Unterstufenschüler in der DDR. Untersuchung der Lehrerzeitschrift „Die Unterstufe“ im Zeitraum 1954 bis 1964. Bad Heilbrunn 2015.

Heinemann, Rebecca: Das Kind als Person. William Stern als Wegbereiter der Kinder- und Jugendforschung 1900 bis 1933. Bad Heilbrunn 2016.

Conrad, Anne/Maier, Alexander (Hrsg.): Erziehung als ,Entfehlerung'. Weltanschauung, Bildung und Geschlecht in der Neuzeit. Bad Heilbrunn 2017.

Müller, Ralf: Die Ordnung der Affekte. Frömmigkeit als Erziehungsideal bei Erasmus von Rotterdam und Philipp Melanchthon. Bad Heilbrunn 2017.

Zimmer, Eva: Wandbilder für die Schulpraxis. Eine historisch-kritische Analyse der Wandbildproduktion des Verlags Schulmann 1925-1987. Bad Heilbrunn 2017.

Horn, Elija: Indien als Erzieher. Orientalismus in der deutschen Reformpädagogik und Jugendbewegung 1918-1933. Bad Heilbrunn 2018.

Haupt, Selma: Das Beharren der Rektoren auf die „Deutsche Universität“. Bad Heilbrunn 2018. Wehren, Sylvia: Erziehung - Körper - Entkörperung. Forschungen zur pädagogischen Theorieentwicklung. Bad Heilbrunn 2020. 


\section{Rita Casale Jeannette Windheuser Monica Ferrari Matteo Morandi \\ (Hrsg.)}

\section{Kulturen der Lehrerbildung in der Sekundarstufe in Italien und Deutschland}

Nationale Formate und ,cross culture 
Der vorliegende Band konnte mithilfe der finanziellen Unterstützung des Lehrstubls für Allgemeine Erziehungswissenschaft / Theorie der Bildung der Bergischen Universität Wuppertal veröffentlicht werden.

Aufgrund einer Vereinbarung zwischen den beiden Verlagen, die die gegenseitige freie Verfügbarkeit der Vertriebsrechte festlegt, erscheint dieser Band zeitgleich in Italien im Verlag FrancoAngeli, herausgegeben von M. Ferrari, M. Morandi, R. Casale und J. Windheuser, unter dem Titel La formazione degli insegnanti della secondaria in Italia e in Germania. Una questione culturale.

Die Herausgeber*innen bedanken sich bei dem Künstler Pippo Leocata für die kostenfreie Überlassung des Titelbildes.

Dieser Titel wurde in das Programm des Verlages mittels eines Peer-Review-Verfahrens aufgenommen. Für weitere Informationen siehe www.klinkhardt.de.

Bibliografische Information der Deutschen Nationalbibliothek Die Deutsche Nationalbibliothek verzeichnet diese Publikation in der Deutschen Nationalbibliografie; detaillierte bibliografische Daten sind im Internet abrufbar über http://dnb.d-nb.de.

2021.lg. ( ) by Julius Klinkhardt.

Grafik Umschlagseite 1: () by Pippo Leocata, La città delle parole [Die Stadt der Worte], Öl und Acryl auf Leinwand, 2014. (Privatsammlung)

Druck und Bindung: Bookstation GmbH, Anzing.

Printed in Germany 2021.

Gedruckt auf chlorfrei gebleichtem alterungsbeständigem Papier.

Die Publikation (mit Ausnahme aller Fotos, Grafiken und Abbildungen) ist veröffentlicht unter der Creative Commons-Lizenz: CC BY-NC-ND 4.0 International https://creativecommons.org/licenses/by-nc-nd/4.0/ 


\section{Inhaltsverzeichnis}

\section{Einführung}

Nationale Fälle und cross culture in der Lehrerbildung

Rita Casale, Monica Ferrari, Matteo Morandi und Jeannette Windheuser .7

\section{Italien}

Habsburg Legislation on the Training of Elementary and Ginnasio-Liceo (Secondary) Teachers and its Implementation in the Italian Territories across the $18^{\text {th }}$ and $19^{\text {th }}$ Centuries

Simonetta Polenghi

The Scuola Normale Superiore di Pisa: between French Model and Autonomous Choices (1810-1923)

Paola Carlucci und Mauro Moretti

Long-Term Issues in Secondary School Teacher Training in Italy

(1862-2015)

Matteo Morandi

Belgium as a Cultural Model for Building the Italian Secondary School and Training its Teachers (1860-1900)

Mara Donato di Paola

An Atypical Path of Women Teachers Training, between the $19^{\text {th }}$ and $20^{\text {th }}$ Centuries: the Istituti Superiori di Magistero femminile

(Higher Institutes of Teaching for Women)

Tiziana Pironi

The Professor of Pedagogy and Italian Textbooks between the $19^{\text {th }}$ and the $20^{\text {th }}$ Centuries

Giuseppe Zago

Pedagogy in the Training Experience of Italian Secondary School Teachers

from SSIS to FIT (and beyond?) (1998-2019)

Monica Ferrari

Training Secondary-School Teachers and the Position of the Minor.

Reflections from a Juridical-Constitutional Perspective

Giuditta Matucci 
The Role of Pedagogy in the Initial Training of Teachers of the Italian Secondary School Today Anna Bondioli, Maurizio Piseri und Donatella Savio

\section{Deutschland}

Seminare - eine hybride Ausbildungsform (18. bis 19. Jahrhundert)

Sabine Reh und Joachim Scholz

Gymnasiallehrer im Vormärz (1830-1848):

Zwischen Wissenschaft und Lehrberuf

Margret Kraul

Geisteswissenschaftliche Pädagogik und

höhere Lehrerausbildung (1915-1960)

Eva Matthes

Modernisierung durch Feminisierung? Zur Geschichte der

Lehrerinnenbildung in Deutschland (19. und frühes 20. Jahrhundert)

Elke Kleinau

Die Lehrerausbildung in der Bundesrepublik seit 1990: die Gründung

der Schools of Education

Charlotte Röhner

Die Entpädagogisierung der Lehrerbildung in der Bundesrepublik und die Entstehung der Bildungswissenschaft als Leitdisziplin in den 1990er Jahren

Rita Casale

Zur Heterogenität des Lehramtsstudiums in Deutschland:

Interaktionsanalysen universitärer Lehrkulturen (21. Jahrhundert)

Imke Kollmer, Hannes König, Thomas Wenzl und Andreas Wernet

Sexuelle Bildung: Geschichtliche und curriculare Perspektiven in der Lehrer/innenbildung

Julia Kerstin Maria Siemoneit und Jeannette Windheuser

Entwicklungen der Lehrerbildung in Deutschland

Jürgen Oelkers 


\title{
Belgium as a Cultural Model for Building the Italian Secondary School and Training its Teachers (1860-1900)
}

\author{
by Mara Donato Di Paola
}

In 1868, only a few years after the Italian unification, the scholar Pasquale Villari, then Director of the Scuola Normale Superiore of Pisa, was among the first Italian intellectuals to go abroad with the view to studying foreign school models. ${ }^{1}$ As he mentioned in the preface of his book Scritti pedagogici, the excursion to Germany he undertook at his own expense during the university holidays aimed at 'examining the secondary schools $[\ldots]$ and historical and philological (German) seminars [...] whose teaching meet a success that the whole Europe admires'. ${ }^{2}$ As he explicitly stated, his objective was to draw from a comparison with the German gymnasiums some conclusions able to help improving the Italian school system.

The Italian interest in foreign models can be explained in the light of the political, social and economic situation of the young Kingdom of Italy at the time. Striving to define a national school model and worrying about the country's backwardness in education after unification, many Italian intellectuals like Villari - undoubtedly one of the most famous examples - showed great interest in foreign educational models, from which they sought to draw inspiration. Supported by the political class of the time and the Ministry of Public Education, these xenophilic authors, through their excursions abroad and their publications on the subject, fuelled the national debate on the changes that had to be introduced in the existing scholastic apparatus and got deeply involved in the definition and construction of the national school system.

Historiography has amply documented the fascination exerted by the German, and partly French, scholastic models on the Italian school system (at the primary, secondary ${ }^{3}$ and university ${ }^{4}$ levels), emphasising features directly imported from both models. ${ }^{5}$ Few studies have explored other ways and proposed a reflection on the influence of models from other countries. During the post-unification years, however, a brief look at the production of that time shows that Italian scholars took into consideration and studied other foreign school systems. ${ }^{6}$ Here, we propose to explore the interest shown by Italian legislators towards a lesser-known cultural model: the Belgian school system. After tracing the origins of the curiosity of European and Italian legislators for foreign models, we will study in depth the interest shown by

1 I thank Dr. Laura Fanti, colleague and friend, for her precious reading (and stylistic suggestions for the Italian version of this article).

2 Villari 1868, p. 315.

3 See Marin 2010.

4 On the foreign models that inspired the Casati Law, see in chronological order: Valentini 1959; La Penna 1993; Porciani 1994.

5 We refer, for example, to the question of introducing Greek into Italian secondary school programmes after the unification, directly inspired by the German model (see Benedetto 2012). We are also thinking about the influence exerted by the French model on the genesis of the Consiglio Superiore della Pubblica Istruzione (see Ciampi/Santangeli 1994).

6 See in chronological order: Miotti 1863; Macchi 1864; Scavia 1866; Petrucelli della Gattina 1879; Bonghi 1888, 1889; Rossi 1889. 
the Italian political class towards some aspects of the Belgian scholastic model. We will show the methods they used to study this model and the limitations they faced in transferring some of its characteristics. As we will try to demonstrate, even if a series of features of the Belgian model could not be transposed into the Italian national system for ideological, economic or cultural reasons, the study of the Belgian school system, and more generally of foreign cultural models, undoubtedly played a role in the development of the Italian national school system in the post-unification years. It is therefore legitimate to state that the comparison with foreign school models contributed to the building of the modern Italian school.

\section{A look at Italy: foreign reflections on the subalpine school model in the post-unification years}

The English poet and school inspector Matthew Arnold, a member of the Schools Inquiry Commission, was commissioned by the British government in 1865 to travel in Europe to study foreign school models. Established in 1864, this commission, better known as the Taunton Commission, was the product of the first major national initiative launched by the English government to explore the situation of secondary education in England and Wales and analyse foreign school models used beyond the Anglo-Saxon world. As emphasised in the report given to her Majesty the Queen, the aim of the study of foreign models was not to identify schemes adopted by other countries and copy them, but rather to look for inspiration. More precisely, the idea was to assess how foreign lawmakers had managed the challenges imposed by modern society in order to adapt the training offered to young people to the needs of a diversified public no longer confined to future members of liberal professions. ${ }^{7}$

Charged with the task of studying the French, German, Swiss and Italian secondary education systems, the English scholar wrote a book based upon his roughly seven-month assignment entitled School and University on the Continent (1868), in which he carefully collected the insights of his observations. For the English poet, it was neither his first experience abroad nor his first publication concerning foreign school models. It was, however, Arnold's first opportunity to closely examine the Italian school system, which received a moderate judgment. While acknowledging the efforts made by the Piedmontese government, in particular by Count Cavour, to give the State the authority necessary to strengthen secondary education and reinvigorate studies - elements, in his opinion, that were essential for the revival of the country - Arnold expressed a certain uneasiness about the unresolved problems on the peninsula. Referring to the period following unification, he did not fail to underline the many difficulties encountered by the State and the school authorities in dealing with the problems that weakened the Italian school system: the significance of the Church and its schools (which competed with government schools); the financial difficulties encountered by the administration in subsidising the public school system; the poor performance of pupils; the lack of preparation on the part of the professors; the inadequate standardisation of school legislation; the deficient character of teaching programmes, and so on. ${ }^{8}$

7 See Schools Inquiry Commission. Vol I: Report of the Commissioners, presented to both Houses of Parliament by Command of Her Majesty (London 1868), p. 50. On debates relating to that period, it is suggested to read Müller/ Ringer/Simon 1987.

8 See Arnold 1868, pp. 150 f. 
Arnold was by no means the sole voice expressing such impressions with the context of Europe. Roughly ten years later, the French educator Célestin Hippeau expressed a similar view in his essay L'instruction publique en Italie (1875). In this essay, the French scholar offered his readers a detailed analysis of the Italian school system. He emphasised the fragility of the Italian educational sector, which he defined as an apparatus still in search of solid foundations on which to build a strong public system. ${ }^{9}$ Hippeau's interest in foreign school models must be seen in the wake of the battle of Sedan. Attributing their military defeat to the soldiers' lower level of education (compared to that of the Prussian soldiers), the French authorities reflected on the deficiencies of their national school system. ${ }^{10}$

Arnold's and Hippeau's essays are just two examples of the rich body of literature of the time devoted to the Italian school model. The outcome of 'pedagogical missions' commissioned by governments, these reports were written for legislators, with a view to providing a series of information and documents that were intended to facilitate and stimulate the process of reflection regarding the changes to be introduced to the national school system. The interest shown by the European legislators in foreign school models must be considered in the light of the political and social situation that the great European powers were experiencing. During the second half of the nineteenth century, against the background of rapid industrialisation and the emergence of a small and medium bourgeoisie eager to educate itself, many voices began to criticise classical secondary education - in other words, literary and animated by a non-utilitarian view of knowledge, which was judged unsuitable to the needs of modern society. ${ }^{11}$ European states, in rethinking their national educational systems and reforming existing educational structures, were confronted with the necessity of responding to both this new social need and the new challenges connected with a more utilitarian vision of society. ${ }^{12}$ It was a matter of adapting the institutional structure and the pedagogical objectives in a manner that would allow the school system to provide for the training of a sufficient number of new economic actors that society increasingly need. ${ }^{13}$

To this end, the political leaders of European countries, attentive to what was happening elsewhere, strove to find ideas and solutions beyond national borders. Among the various means they used (pedagogical missions abroad, inspection reports and international congresses), the pedagogical journey undoubtedly turned out to be the most interesting and widespread instrument. A valuable assessment tool - one simultaneously able to provide elements of pedagogical reflection, educational documentation and political-scholastic analyses - the journey gave the means to collect a set of data that, combined in various ways, allowed for the comparison of different models and educational systems. ${ }^{14}$

Keeping in mind the situation of the Italian school system in the post-unification years, as described by Arnold and Hippeau, one can put into perspective the lessons that the two scholars gleaned from their trip in Italy. Mirroring opinions expressed by the Italian intellectuals themselves, characterised by pronounced worries regarding the situation of the country's edu-

\footnotetext{
9 See Hippeau 1875, p. VI.

10 See Bourquin 1993.

11 See Raicich 1981.

12 See Caron 2007.

13 See Matasci 2015.

14 See Zymek 1975.
} 
cational system, ${ }^{15}$ Arnold's and Hippeau's respective analyses clearly demonstrated the existing Italian model was still not firmly enough planted on its foundations. As such, they felt it was far from being on par with the other European powers and were rather fascinated by other models, with a clear preference for the German one. ${ }^{16}$ In a phase of political, geographical and cultural consolidation, and in a state of permanent tension with the Catholic Church, Italy was predominantly seen as a 'laboratory' to be observed with curiosity rather than as a viable alternative worthy of imitation.

\section{Taking a page from the others? The interest of Italian legislators in European school models}

Looking from the opposite direction, the perspective of Italian lawmakers towards foreign school models could hardly have been more different. Striving to build a national school model that addressed the backwardness they saw in the Italian educational system, Italian rulers were from the very establishment of the kingdom greatly interested in and sought to draw inspiration from foreign educational models. Their counterparts in other European countries could rely on tried-and-tested educational structures. This was not the case in Italy, and the leaders were fully aware of the difficult and precarious state of the national school system. As the commission's 1867 draft law on the organisation of secondary education (to be presented to the Senate) showed, a systematic comparison with other European school systems revealed that the Italian system, as it was then organised, was clearly inferior to what existed in other countries. The number of students was significantly 'below' what was required 'for the needs of society and what it was in the other States in Europe'. ${ }^{17}$ The numerical comparison with other nations was horrifying. While 115,000 pupils attended the secondary State schools in Germany and 34,442 in France, in Italy only 4000 pupils (in the same period of time) attended the 78 licei governativi (State secondary schools) and 10 licei paritari (private secondary schools that received State recognition) that were scattered throughout the various regions of the peninsula. ${ }^{18}$ Even more serious than the low number of pupils was the 'evidence of the unhappy conditions of studies and examinations, when compared to the situation in German and foreign secondary schools in general'. ${ }^{19}$ This was further compounded by the poor preparation of Italian professors, who were themselves poorly trained at the kingdom's universities, and certainly had every reason to be envious of the conditions at German seminars and the French Ecole Normale Supérieure of Paris. ${ }^{20}$ In conclusion, according to the members of the commission, everything would have to be done over again.

On the theoretical level, everyone was more or less in agreement that the current organisation and structure of the classical Italian school was unable to respond to the high ideals according

15 On the difficulties encountered by Italian legislators in the first post-unification years, see Fiorelli 2012; Lacaita/ Fugazza 2013.

16 For England and France, see Armytage 1969; Mombert 2010.

17 Senato del Regno. Sessione 1867. Relazione della Commissione composta dei Senatori Matteucci, Amari, Brioschi, Cibrario, Lambruschini, Sagredo e Mamiani sul progetto di legge per l'insegnamento secondario (N. 27-A) (Firenze 1869), p. 2.

18 Cf. ibid., p. 3.

19 Ibid., p. 4

20 Cf. ibid., p. 6. 
to which it was conceived, namely the training of the future ruling class of the country, i.e. the connective tissue of the nation. From a practical point of view, the solutions to be adopted did not seem so easy to implement. As explained above, various economic, political, cultural and structural obstacles made the development of a national school system difficult and laborious. Confronted with a high illiteracy rate in most Italian regions, the difficulties of the State in defining an educational policy and the urgent need to proceed with the cultural unification of the country, the Italian politicians who succeeded at the Ministry decided to take an interest in the best foreign models. ${ }^{21}$ Several reasons led the Italian ruling class to seek solutions beyond national borders. First of all, the xenophile character of this ruling class, who were essentially of subalpine and Lombard origin. Having grown up within the context of the Central European culture, trained in the Habsburg school system - one of the most advanced school systems in Europe - the men serving in government were educated within a xenophile environment, where the models of the most advanced countries in Europe (France, Austria, Germany) were looked upon favourably. The second reason that prompted Italian rulers to seek solutions elsewhere was the inexistence of an organised and efficient national school system, with the exception, as mentioned before, of the Lombardo-Veneto system. Finally, the last reason, and the most important, was the awareness that education was the basis of a nation's power (in terms of economic progress, industrial development and military power). Taking other European nations as role models, the Italian legislators felt that education could be a powerful instrument to make the country economically prosperous while unifying the citizens culturally, geographically and ideologically. ${ }^{22}$

The study of foreign models carried out by the Italian ruling class in the post-unification years continued to develop, using various sources of information (pedagogical missions, surveys, conferences, universal exhibitions), until the end of the century. Two phases can be distinguished in the time span between the unification and the end of the nineteenth century. The first period (1860-1874) provided a basis of ideas able to help strengthen the existing school system by shaping secondary education according to solid foreign European models, with a clear preference for the German school system. ${ }^{23}$ In the second phase (1874-1900), studies were launched on certain topics with the aim of drawing inspiration from foreign examples before introducing partial and precise modifications into the existing system. Suffice it to say that, during this second phase, as many as 24 reports of scholastic and pedagogical interest were published by the Bollettino ufficiale del Ministero dell'Istruzione Pubblica (the Official Bulletin of the Ministry of Public Education). ${ }^{24}$ The product of missions carried out in Europe and the United States by university professors, inspectors, officials and teachers, on behalf of the Ministry, these publications were devoted to various topics relating to the scholastic world such as manual labour, patronage, gymnastics courses or school books. ${ }^{25}$ Far from being arbitrary, the missions abroad were conceived from the beginning as an important preliminary assessment tool for the modifications that the legislators wanted to introduce to the national

21 Cf. Targhetta 2010 , p. 155.

22 Cf. ibid., pp. $155 \mathrm{ff}$.

23 See in chronological order: Parola/Botta 1851; Villari 1868; Pullé 1877; Scopoli 1879; Denicotti 1874; Piazzi 1894.

24 Information on these missions can be found in the communication presented by Giorgio Chiosso at the CIRSE conference held in Padua on 05/30/2003 and entitled: I Musei dell'educazione: storia e prospettive. I thank prof. Chiosso for kindly making the text of his report available.

25 See ibid. 
system. Beyond their interest in terms of knowledge, they also undoubtedly represented an opportunity to get to know the specific foreign school systems, and thus enabled a critical engagement with the Italian school system. ${ }^{26}$

\section{Similarities between Belgium and Italy: comparison of two young nations}

Since the early days of the current scholastic legal framework, the Italian legislators showed great interest in the school models of the great European powers - Germany, England and France - from which they took significant inspiration. They also showed a certain attraction towards the Belgian educational system. As Professor Luigi Luzzatti pointed out in his 1867 essay, even if Belgium was a small and very recently formed nation, in many respects the kingdom could certainly serve as a model for consideration, in particular due to the very modern constitution and the liberties (including those of religious worship, printing and teaching) it proclaimed. ${ }^{27}$

Beside these novel features, underlined and admired throughout Europe, the attractiveness of Belgium for Italy stemmed from the very similar situation of the two countries at the beginning of the century. Both were young states in search of a strong national identity, which they needed to construct against the background of a varied geographical, political and cultural past. Among the various challenges they were facing, both countries had to erect, on the bases inherited from past regimes, a national school system capable of homogenising, rearranging and making multifaceted school habits converge. In both cases, it was above all a matter of providing a varied scholastic offer organised in various teaching cycles (classical and technical education) addressed to different scholastic publics. ${ }^{28}$ In Belgium, where the first law on secondary education was only voted on in 1850 , this process progressively developed through the promulgation of a series of circulars. ${ }^{29}$ In Italy, on the other hand, where a law framing secondary education (the Casati law) existed prior to unification, the aim was to extend the subalpine school legislation to the whole peninsula. ${ }^{30}$ Finally, both in Belgium and in Italy, the presence of a very important Catholic party had forced the other political parties (especially the liberal one) to take a position on the relationship between State and Church and the prerogatives that could be abandoned in matters of education. ${ }^{31}$

These facts help us to understand Italian legislators' interest in the Belgian school model. Other school systems of the time had been more tested. Constructed only about ten years prior to the promulgation of the Casati law, the Belgian model had the advantage of having been conceived in a context very similar to the one that the Italian legislators were facing. The literature on the Belgian school system indicates that the Italian legislators showed a clear interest in three specific aspects: the scholastic freedom, admired in the main European countries; the training of secondary-school teachers, based on a hybrid system between the German model and the

26 Cf. Targhetta 2010, p. 159.

27 Cf. Luzzatti 1867, pp. 1f.

28 See Donato Di Paola 2018.

29 See Grootaers 1998.

30 See Talamo 1960.

31 See De Groof/ Glenn 2002/2003. On the specific Italian case, see Pazzaglia 1965; Talamanca 1975. 
French one; and the technical education, considered particularly advanced for the time. In all three cases, these were characteristics that Italy wished to implement in its own school system.

\section{Belgian educational freedom: an impossible model to imitate?}

The reasons that pushed Italian legislators to take an interest in Belgian school freedom can be easily understood. In a historical period in which European states wanted to take charge of education and become an important point of reference in its development, how much room should be left to the Church and the religious institutions in school matters? Given the slowness shown by the Catholic Church in giving up its temporal power, to what extent was it possible to establish scholastic freedom in the new Kingdom of Italy? To answer this question, Italy looked to several European models for inspiration. As the school inspector Dino Carina explained in his 1861 essay, every European nation confronted with this question ended up proposing a different solution. In France, for example, the law regulating public education had granted the government 'broad powers to interfere in teaching', ${ }^{32}$ revoking the right of individuals to manage secondary schools. To restore balance to the situation, the Falloux law of 1850 repealed the state's monopoly on teaching, putting an end to the exclusive right that was recognised by the decree of 17 March 1808, which had organised the Imperial University. In England, state interference was 'barely noticeable' and education was 'almost completely abandoned to the industriousness and zeal of private individuals'. Only in the 1870s, thanks to the Elementary Education Act, did the state begin to intervene in a supplementary way in this area. ${ }^{33}$ Finally, in Belgium the 'beneficial action of the Government and the full freedom of private individuals' were 'reconciled with each other'. ${ }^{34}$ Inscribed in Article 17 of the 1831 Constitution, the principle of scholastic freedom was endorsed in the first law on secondary education (1850), which conferred to the private sector (whether of a confessional nature or not) the right to compete with public schools and to manage its own institutions without any interference by the state in their organisation or supervision. This model, less radical than the French or English ones, was of particular interest to Italian legislators, who extensively studied its origin and application.

As professor Cesare Agostini pointed out in his essay, Belgian scholastic freedom was the product of a compromise between the two great parties of the time, the liberals and the Catholics. These two parties joined forces shortly before the country's independence in a political movement called unionisme (1828-1848), initially set up with the view to resisting the Dutch monarchy. ${ }^{35}$ Once the country's emancipation had been achieved, the unionist government ensured that a series of prerogatives were granted to both political parties in order to preserve the good relations between both factions and to maintain a form of balance between them. It was in this context that the scholastic freedom proclaimed by the 1831 Constitution was implemented, with the effect of correcting the injustice inflicted to the private sector by the former Dutch Government that had denied it the right to manage any type of secondary institution. ${ }^{36}$

32 Harrigan 2001.

33 Cf. Targhetta 2010, p. 157.

34 Carina 1861 , p. 153.

35 Cf. Agostini 1860, p. 185.

36 Cf. Carina 1861, p. 154. 
Because it was able to reconcile two antagonistic visions, and gave the Church great freedom of action, this model was appealing to the Italian Catholics, who defended it strongly for obvious reasons. ${ }^{37}$ Despite the zeal they showed in presenting its strengths and weaknesses ${ }^{38}$ the Belgian model of school freedom was quickly rejected by Italian legislators. To understand the reasons underlying this rejection, we can turn to what the then Minister of Education, Count Gabrio Casati, wrote in his report to his Majesty, an introductory text to the Casati law of 1859. Casati had to present the foreign school models from which Italy took its inspiration to define the role given to the Church and the private sector in the scholastic field. Analysing the definition of freedom in the English, Belgian and German school models, the minister underlined the advantages and disadvantages of the solutions adopted in each system - each quite different - with a view to justifying the choice made by the Italian legislator:

'Three main systems were on offer: that of a full and absolute freedom, which, as in England, excludes any governmental interference; that in which, as in Belgium, private establishments are allowed to compete with State institutions; finally the one practised in many countries of Germany, in which the State, not only provides teaching in its own institutes, but also keep the overall leadership, while admitting competition between private and official teaching. There were not many doubts about which of these systems should be preferred. An unlimited freedom, convenient and appropriate in England, where private individuals have long been accustomed to doing for themselves what is left to the Government elsewhere, could not be experimented here without danger. Even the second system could face serious objections from those who worry about certain peculiar conditions of our country. The safest option was the remaining one, a system of moderate freedom containing the latter within due boundaries, with guarantees ensuring that it will be defended against obvious and hidden enemies, who would distort it and spoil its fruits'. ${ }^{39}$

As Casati explained, the preference for the German system had not been subject to 'many doubts'. In the eyes of Italian legislators, but for different reasons, neither the English nor the Belgian model seemed suitable to the situation the country found itself in. By conferring an absolute freedom to the private sector, the English system contradicted the objectives pursued by the Italian state, namely to take charge of the educational sector. In a country where private individuals are used to putting local interest above those the general public, its adoption would have constituted a 'danger' to be avoided. Although a hybrid, the Belgian model did not represent a reliable alternative. In the eyes of the Italian ruling class, the influence of the Church in the educational sector was simply too great to equip it with such freedom. Fearing strong competition from the religious teaching institutions, which were well established throughout the national territory and enjoyed the sympathy of the local notables, the Italian political class felt that the country was not yet ready to manage the degree of freedom present in the Belgium system. In 1858, a year before the adoption of the Casati law, in a session of the subalpine Parliament, the Minister of Education, Giovanni Lanza, had expressed a very similar idea, warning the defenders of the Belgian model against its possible drifts:

'Then we will see if the Belgian Government from 1830 onwards has not always tried to temper that unlimited freedom of teaching, through reforms that reinvigorated the teaching of the State and

37 Cf. Biancardi 1998, pp. 122ff.

38 See Martini 1854; Arrivabene 1871.

39 Codice dell'istruzione secondaria classica e tecnica e della primaria e normale. Codice dell'istruzione Raccolta delle leggi, regolamenti, istruzioni ed altri provvedimenti governativi emanati in base alla legge 13 novembre 1859 con note spiegative e raffronti colle leggi preesistenti. Approvata dal Ministero della Pubblica Istruzione (Torino 1861), p. 17. 
increased the surveillance of the Government over all other schools. Indeed, by leaving almost entirely the teaching in the hands of private individuals, it allowed it to decay, because it was used in a spirit of speculation, which is never a good counselor in matters of education and progress, or transformed in a weapon within a war against the institutions of the country'. ${ }^{40}$

Once the first two models had been excluded, only the safest one remained, the German system. Indeed, while authorising competition between private and public schools, this model allowed the state to continue exercising administrative control regarding education. The reasons that convinced Italian legislators to opt for a system based on the German model are easy to understand. As Casati explained in his report, given the country's situation, caution advised to opt for a 'moderate system of freedom', in which the state would take responsibility for education and keep control of the guidelines. Accordingly, the government should guarantee 'good methods, diligence in the delivery of teaching, rigor in examinations and the general respect for morality and the principles of moral and religious education [that] had to dominate in all public schools'. ${ }^{41}$ In Italy, the principle of scholastic freedom was therefore more restrictively implemented than in Belgium or England, endowing the state with the right to control, to a certain extent, the operation of private establishments. While ensuring the possibility for private individuals to create educational establishments, the state equipped itself with a series of mechanisms allowing it to maintain a certain degree of control over education: the right of inspection, the choice and selection of school staff, the exclusive authority concerning the organisation of the state exams (the school and secondary school licence exams) and the corresponding degrees. ${ }^{42}$

Far from being universally endorsed, this choice was strongly criticised by those who supported school freedom and defended the idea of improving the level of education through competition between public and private schools. In an 1874 article, La Civiltà Cattolica harshly criticised the attitude of the liberal party, denouncing its behaviour in this matter. According to this newspaper, Italian liberals renounced the beneficial effects of the emulation between institutions belonging to different sectors, as they could be observed in France or Belgium, because they feared the competition between private and public institutions:

'This we see in Belgium; and above all in France, where private colleges are in competition with government secondary schools, resulting in an increase in the level of studies and progress of classical disciplines. [...] We are well aware of the two great objections that the liberal rulers oppose to the freedom of secondary education in Italy. Were we to grant it, the Government institutions would remain almost deserted and almost all the youth would come back under the magisterium of the clergy, which would slowly undo our Italy. Therefore, this freedom is impossible. Therefore, we infer from it, you are false liberals, fake liberals, liberals who use the seed of freedom to mask'. ${ }^{43}$

Far from disappearing, both in Belgium and in Italy, the antagonism between Catholics and liberals in the scholastic field developed over time and continued to fuel great ideological controversies throughout the nineteenth and twentieth centuries. This rivalry can be explained by the importance that both parties attributed to the school sector. After all, taking possession of the educational field meant securing a certain grip on the future generations of the country.

40 Atti del parlamento subalpino. Sessione del 1857-58 (VI legislatura) (Roma 1874), pp. $1149 f$.

41 Sulle condizioni della pubblica istruzione nel Regno d'Italia. Relazione, 1865, p. 234.

42 Cf. Codice dell'istruzione secondaria classica e tecnica, pp. $17 \mathrm{f}$.

43 La questione pedagogica in Italia, La Civiltà Cattolica, 4 (1874), p. 269. 


\section{The German pedagogical seminar and the normal schools of Paris and Liège: three models for the training of Italian teachers}

Although the educational freedom in force in Belgium was not taken as a concrete valuable example by Italian legislators, the Belgian school model continued to arouse their interest over time, with particular attention paid to the training of secondary teachers. This can be explained by the importance paid in the nineteenth century by European States to the figure and role of high school teachers, considered an essential element for the proper functioning of public secondary schools. By embodying the authority of the state on a physical level (through their presence throughout the country) and symbolically (by transmitting a set of collective values), secondary teachers were supposed to constitute the connecting link between the nation and its citizens. To reach this goal, the European states decided to add to the secularisation of their school systems the professionalisation of their teaching staff. ${ }^{44}$

In contrast to the importance given to the new figure of the high school teacher in the scholastic structure of the modern nineteenth-century school, the enquiries carried out throughout Europe had highlighted the deplorable conditions in which European teachers were forced to practise their profession. In Italy, the situation was particularly dramatic. A survey of all high school teachers at the national level carried out in 1865 showed that a 'small number [were] good, a very large number mediocre, and a large number inept'. ${ }^{45}$ The reasons for this situation were well known to the legislative authorities. Due to the low prestige of the profession and the lack of consideration enjoyed by the teachers of secondary school, the faculties of Italian Letters had difficulty in attracting new students. Because of the lack of suitable candidates, secondary schools had to fill vacant chairs with individuals without qualifications and experience. ${ }^{46}$ Poorly paid, poorly trained, and subjected to blackmail by local municipalities that did not guarantee them stable working conditions, the secondary teachers of the peninsula (among whom were a large number of secular priests) could absolutely not be compared with the prestigious figures of the Lehrer of the German Gymnasium ${ }^{47}$ or the Normaliens of the Parisian Lycées. ${ }^{48}$ To raise the level of secondary education, the Italian legislators realised that it was necessary to upgrade the training of secondary teachers. Once again, to determine the best direction to take, Italy sought inspiration from the best foreign models. In 1875, Minister Ruggiero Bonghi instructed professor Luigi Ferri to carefully study the Faculties of Letters and Philosophy of the principal European nations - Germany, France and Belgium - paying particular attention to the training of secondary teaching staff. The task assigned to the Ferri was relatively straightforward: 1) evaluate how these university models had succeeded in reconciling needs that are a priori difficult to combine; 2) find out how to provide the future teachers of secondary education with a good quality professional and practical training while maintaining the scientific and academic character of the Faculties of Letters and Philosophy of the state universities; 3) determine to what extent it would be possible to imitate foreign university systems in that respect; 4) establish which of the three models under scrutiny is the best source of inspiration; 5) ascertain whether it was appropriate

44 Cf. Nóvoa 1998, p. 151.

45 Sulle condizioni della pubblica istruzione nel Regno d'Italia. Relazione, 1865, p. 249.

46 Cf. De Fort 2013, pp. 92f. On the training and profile of Italian high school teachers see Genovesi 1978; Santoni Rugiu/Santamaita 2011.

47 See Bölling 1983.

48 See Gerbod 1965. 
to transform all Italian Faculties of Letters into German-style philological seminars, or perhaps whether it might be more convenient to establish separate high schools independent from the Faculties, following the French model of the École Normale Supérieure; 6) determine whether the Belgian solution, a hybrid model between both systems, might be a good compromise?

As Ferri explained, these models were very different. In Germany, future secondary teachers were trained through two mechanisms. On the one hand, there were the famous scientific seminars, admired throughout Europe, which were organised in various centres of higher education. Their purpose was to train people 'capable of transmitting their science to others [and to] form scholars in a given discipline through a set of practical exercises on common subjects, leaving specialized matters to conferences and the direct interaction between students and professors'. ${ }^{49}$ On the other hand, there were the pedagogical seminars proposing a practical training limited to a few hours of attendance at lectures given by secondary-school teachers. ${ }^{50}$ In France, the training of secondary-school teachers was ensured by the École Normale Supérieure of Paris, a centre of higher education completely separate from state universities, in which letters and sciences were taught in two distinct sections. ${ }^{51}$ Admitted through a competition, the pupils of the École Normale (who lived within the establishment), constituted a sort of aristocracy of the academic world. They received a three-year education, including a one-month internship in a Parisian secondary school. At the end of the three years, the candidates of the École Normale, together with those coming from the Faculty of Letters, applied to the Agrégation, a national competition enabling those selected to teach in secondary school. ${ }^{52}$ Finally, in Belgium, the training of secondary-school teachers relied on a hybrid system that managed to reconcile the complementary visions proposed by both systems and combined 'the two methods in a just measure'. ${ }^{53}$ It was ensured by two high schools annexed to the University: the École Normale des Humanités of Liège for the Letters, and that of Ghent for the Sciences. ${ }^{54}$ Copying the French model's ideas of admitting the students through a competition and hosting them in a college, the Ecole Normale of Liege offered a four-year education divided into two parts: a theoretical component given at university, modelled on the German scientific seminars, and a practical part within the school, directly inspired by the French system. At the end of their schooling, the twenty scholarship holders were required to apply to the exam of aspirant agrégé that enabled them to teach in one of the secondary schools of the kingdom. Evaluated by a mixed committee of professors from the state universities of Liège and Ghent and two private universities (the Free University of Brussels and the Catholic University of Louvain), the graduates from the École Normale of Liège, as beneficiaries of a fellowship from the state, were obliged to work in public schools for at least two consecutive years. ${ }^{55}$

While acknowledging the advantages of all models, Ferri did not fail to emphasise their respective defects. In his opinion, the German model was too theoretical; the French one proposed too short a training, and the Belgian lacked of a sufficiently strong disciplinary specialisation. Above all, by training only a small number of candidates and allowing mixed university juries to evaluate them, the Belgian system could not be considered as a valid model for a country as

\footnotetext{
49 Ferri 1875 , p. 299.

50 Cf. ibid., pp. $298 f f$.

51 See Masson 1994.

52 Cf. Ferri 1875, p. 322.

53 Ibid., p. 325.

54 On the Belgian university model see Dhondt 2011.

55 Cf. Ferri 1875, pp. 331ff.
} 
large and varied as Italy, which had to train a great number of professors and where the state wanted to keep its monopoly on the awarding of university degrees. For these reasons, the Italian scholar concluded that no foreign model could be completely imitated. One had to start from the situation of Italian higher education in this area: the absence of specific training for secondary teachers, and the fact that the candidates applying to competitions for vacant chairs were provided with either a university degree in a given discipline or a diploma conferred by one of the four normal schools scattered throughout the country (Naples, Pisa, Florence and the Padua seminar). Ferri proposed to Minister Bonghi to borrow some positive elements from each European model, trying to adapt them to the Italian system. The objective was to reinforce the training of Italian secondary teachers, and 'help with means the development of the practical and serious part of literary, philosophical and positive studies, not to mention their connection and reciprocal fertilization in universities'. To this aim, he proposed to borrow from the German system the idea of professorial lectures, by organising special courses given by independent professors with 'the aim of raising the studies and of helping the preparation of future teachers of secondary schools'.$^{56}$ Drawing from the French system, he suggested to harmonise the regulations of Italian normal schools; to create specific diplomas for teachers; to upgrade the title of teacher or assistant teacher in secondary classical and technical education; to award this title on the basis of a national competition (instead of local competitions), open to candidates with a university degree or having completed a professional internship. In his view, such measures would help raise the level of training and improve the working conditions of the teachers and their careers. From the Belgian model, Ferri kept the idea to refuse separating completely (as in France) normal schools and universities. Indeed, in his mind, the state should keep its exclusive role in the awarding of diplomas and the control over the training of secondary-school teachers. However, reminding the minister of the current situation of Italy in this area (little economic means for the training of teachers, insufficient number of adequately trained professors and few colleges where the trainees could practise), he advised him to open, with caution, a small number of normal schools. Later, with the improvement of education and the country's economic conditions, the possibility could be assessed to open a greater number of such institutions. ${ }^{57}$ Far from constituting the subject of a brief moment, the training of secondary professors continued to arouse debates and reflections over time. Thanks to the reforms implemented all through the nineteenth and twentieth centuries by Italian legislators, inspired by European models, the level of Italian secondary teaching increased considerably. Gradually, the figure of the amateur professor disappeared, making way for that of the well-trained, qualified secondary school teacher we know today.

\section{Belgian technical education: a leading-edge school model}

An aspect of the Belgian system used as a model by Italian legislators in very concrete fashion one of the most relevant - concerns technical education. The interest of the Italian ruling class in this characteristic can be easily explained. Compared to what could be found in other European countries in this respect, Italian technical education suffered from serious backwardness. Before unification, it simply did not exist outside some regions such as the Lombard-Veneto

56 Ibid., p. 339.

57 Cf. ibid., pp. $344 f f$. 
Kingdom or the Kingdom of Sardinia. An effort had been made to organise it with the Casati law of 1859 , but the implementation of the law had been so slow that it took a long time to expand its application over the whole Italian territory. ${ }^{58}$ Looking at the Belgian school system, Italian legislators were keen to take inspiration from a leading-edge model admired in the whole of Europe. As early as 1850 , Belgium had a very modern school system structured in two different cycles. The prestigious athénées royaux, which offered a seven-year cycle of studies; or the lower-level écoles moyennes, which proposed a three-year degree course. Attended by the children of the bourgeoisie, the athénées proposed training tailored to the needs of those willing to start university courses with the view to access a liberal or scientific profession. Each athénée had two sections: the section des humanités, preparing for liberal careers (in Italy, the equivalent was the liceo classico), and the section professionnelle, preparing for scientific faculties. The students of the two sections attended the same courses, with some exceptions for subjects only taught in particular sections according to the chosen field. In the section professionnelle, for instance, classical languages were replaced by modern languages and scientific disciplines. The écoles moyennes were attended by a more modest public eager to receive a short training allowing to enter early into the world of work. By offering a system structured in two alternative training cycles allowing to reconcile different expectations, the Belgian model perfectly responded to the challenge of modern times.

The effectiveness of this double system of schools, ever more numerous and frequented, had not escaped Italian observers, who emphasised their merits all through the nineteenth century. Already in 1861, the school inspector Dino Carina praised the technical education in Belgium, emphasising the importance given to the study of scientific subjects (considered indispensable in a modern society) and highlighting the results obtained by the section professionnelle of Belgian secondary schools:

'The technical courses of the Athénées serve to train neither workers nor scientists. But they succeed admirably in spreading much of the knowledge that matches the needs of civil life. [...] A technological teaching addressed to the middle classes of society that accustoms the youth to value the importance of such studies is worthy of attention. This was widely achieved in Belgium with the organization of technical schools in the Athénées Royaux'. ${ }^{59}$

Six years later, the members of the commission responsible for presenting a bill to the Senate underlined in turn the success of the Belgian, Swiss and German technical schools, which were more and more frequented and 'multiplied every day'. Noting that an analogous phenomenon could be observed in Italy, where the technical schools were the only scholastic sector that had progressed, they invited to take inspiration from what was done elsewhere to try to improve the Italian technical training offer ${ }^{60}$ As a matter of fact, even though they met some success, the Italian technical schools as they were structured could not be compared to their European counterparts. Categorising them as second-class schools, the Casati law had placed them in a situation of clear inferiority compared to the classical secondary establishments, considered the pathway to excellence. To remedy this situation with the view to providing Italy with highly qualified scientific staff, those who advocated for the scientific disciplines strove to encourage

58 See Lacaita 2012.

59 Carina 1861, p. 186.

60 Cf. Senato del Regno. Sessione 1867, p. 18. 
the Italian legislators to take inspiration from more advanced countries such as Belgium, Germany or France, where the technical teaching was a winning asset.

Despite pressures from the industrial world, an opportunity to rethink the structure of the Italian technical school only appeared at the end of the century. By favouring a further development of scientific disciplines in European curricula, the reforms that took place at the end of the nineteenth century in most European countries pushed Italian legislators to reflect on the place of technical education in Italy. On the one hand, it was necessary to determine the weight to be given to classical culture in Italian secondary schools; on the other hand, the aim was to assess the relevance of strengthening the mathematical and naturalistic disciplines in the Italian secondary school through a revision of programmes, it being understood that this would mean downsizing classical culture. ${ }^{61}$

Here also, Italian intellectuals looked for alternatives beyond national borders. Among the various models taken into consideration by the Italian legislators at the end of the century, the Belgian model continued to enjoy a fair amount of attention. In 1872, the lawyer Massimiliano Giarrè, professor of technical education in Florence, undertook at his own expense a trip to the main areas of Northern Europe (Bavaria, Austria, Saxony, Prussia, Belgium and England) to study the development of technical education. ${ }^{62}$ Eight years later, Alberto Errera, professor at the Royal Technical Institute of Naples, was commissioned by the government to present a detailed study of the Belgian school system, paying particular attention to its technical education. ${ }^{63}$ Finally, in 1882, the secondary-school teacher Riccardo Folli published an important comparative study on foreign school systems entitled Le scuole secondarie classiche straniere e italiane: confronti, note e proposte. Taking into account current events and denouncing the situation of Italian classical education, Folli stressed that neither the passage of time nor reforms had succeeded in improving the national school system. Analysing the results obtained where the school systems had been reformed, he demonstrated the need to implement the same type of reforms in Italy. Referring to the recent Belgian reform of 1881, which had given more space to scientific subjects, Folli emphasised the advantages the country had gained. ${ }^{64}$ Profoundly influenced by the German school system, the Belgian reform of 1881 had led to the creation of a varied educational offer able to respond to the needs of modern society. Next to the pre-existing sections of the Athénées, the humanités and professionnelle sections, renamed respectively humanités gréco-latines and humanités modernes, the Belgian reform had created a new section called humanités latines-mathématiques. As previously mentioned, the first two sections focused respectively on the study of literary and scientific disciplines. By simultaneously proposing a scientific and classical education (in fact only one classical language, Latin was taught), the new section of humanités latines-mathématiques constituted a compromise between them. Set up in this way, the Belgian school system copied largely the German educational model: the first section corresponded to the German Gymnasium (whose equivalent in Italy was the liceo classico), the second to the Realschule (to which corresponded the Italian technical institute) and the third to the Realgymnasium (without equivalent in Italy). ${ }^{65}$ Each section gave access to different university faculties, according to the needs of modern society. Only the students coming from humanités gréco-latines were allowed to enter any university

61 Cf. Cerasi 1998, pp. 123ff.

62 See Giarrè 1872.

63 See Errera 1880.

64 See Folli 1882.

65 Cf. Donato Di Paola 2018, p. 67. 
course. Those who had attended the other sections had to pass additional exams to enrol in faculties which didn't correspond to the courses that they had followed. The Belgian reform of 1881 was designed bearing in mind the willingness to safeguard the elitist nature of classical studies. To the satisfaction of those who defended scientific studies and exerted in this respect an ever-greater pressure on public opinion, the reform established a more varied educational offer. But it maintained and reinforced also the principle of a superiority of classical education. A complete equivalence of diplomas was not on the agenda. Although heavily criticised, this situation would last a long time. The first measures in favour of a (partial) equivalence of diplomas for the access to university were voted only in the $1940 \mathrm{~s}^{66}$

The models of Belgian and German technical schools presented considerable advantages. But for something similar to be proposed in Italy, it would be necessary to wait until the beginning of the twentieth century. The Royal Commission of 1905 in charge of reflecting on the restructuring of the Italian school system, in its reform project of 1909, proposed the establishment, on an experimental basis, of three categories of secondary schools: the classical liceo classico (equivalent to the German Gymnasium and to the Belgian section of humanités gréco-latines), where the study of classical languages was maintained, the liceo moderno (equivalent to the Realgymnasium and the Belgian section of humanités latines-mathématiques), where only the study of Latin was kept, and the liceo scientifico (equivalent to the Realschule and the Belgian section of humanités modernes), where classical languages were not taught. ${ }^{67}$ Crystallising the tensions between the partisans of classical education and scientific subjects, the 1909 reform caused considerable controversy. The bone of contention was the question of access to university faculties: should only classical secondary schools give access to all university faculties, or could students who attended other types of schools enjoy this possibility? In the end, the partisans of the first system won. The 1909 reform granted access to all faculties only to students coming from classical schools. The others could only attend university courses corresponding to their basic training. In reality, even if it satisfied the 'classicists', the 1909 reform, considered too advanced for the mentality of the time, was never implemented. It would be necessary to wait for the law of 21 July 1911 to see a modern secondary-school system in Italy. Established, contrary to the provisions of the 1909 reform, only in nine model cities on an experimental basis, it relied on a new form of liceo moderno, giving all students access to all university faculties. But this new liceo moderno did not have a very long life. With the Gentile reform of 1923, it was replaced by the liceo scientifico, where Latin was still taught but which did not give access to all university faculties. Through this move, Gentile reinforced the humanistic structure of the Italian classical secondary school and restored the predominance of classical Italian culture. The Italian philosopher put an end to the most serious attempt to modernise the Italian school system undertaken during the nineteenth century by the Italian political class. ${ }^{68}$

66 Cf. Grootaers 1998, pp. 276f.

67 See Ministero della pubblica istruzione. Commissione Reale per l'ordinamento degli studi secondari in Italia. Vol. 1: Relazione (Roma 1909).

68 Cf. Bonetta/Fioravanti 1995, p. 76. 


\section{Between Models and Reforms}

As we have tried to demonstrate by analysing the interest shown by Italian legislators in European cultural models, especially the Belgian school system, the study of foreign school systems became an important instrument of expertise in the nineteenth century in Europe. In a context of strong international competition and intense reflection on scholastic models, many educationalists, intellectuals and school legislators of the time, animated by a desire to 'know the other' and to measure themselves with it, embarked on the discovery of foreign school models, ${ }^{69}$ taking part in what has been defined as an international 'reforming nebula'. ${ }^{70}$ It was only later, starting in the 1920s, that interest in foreign models was truly accompanied by a desire to 'understand the other ${ }^{\text {'71 }}$ in its diversity. This geographic opening, helped by advances in communication in a phase defined by many historians as 'the first globalization', ${ }^{72}$ facilitated the diffusion of some models judged as particularly high-performing and positive and led to a certain homogenisation of the European scholastic panorama. The reforms undertaken in the various European countries generally followed the same direction, converging towards the great reforms of the end of the century that recognised the equivalence of school diplomas. But their implementation took place at different speeds according to national peculiarities and intrinsic rhythms. ${ }^{73}$ In Germany and France, these changes occurred relatively early (in 1900 and 1902, respectively). But in Italy and Belgium the complete equivalence was achieved later, much later in the twentieth century (in 1969 and 1964 respectively). Although, as the analysis of this case shows, the study of foreign models did not always lead to concrete and immediate reforms, it nevertheless contributed to nurturing the reflection on the reforms that were wished to be implemented. In Italy, in particular, it undoubtedly supported the development of the national school system in the post-unification years. At the end of the day, the expertise based on foreign systems served above all to avoid reproducing experiments that had not worked elsewhere (by identifying the weaknesses of the other school systems), to take inspiration from changes that were positive, legitimise the perceived needs through the comparison with other European states, and find solutions better suited to the concrete, singular needs of each country.

Analysing the birth of the Italian secondary-school policy in the early post-unification years in the light of Italian interest in foreign models, by decentralising from an exclusively national vision, allows to identify the weak and strong points of the development of the Italian school system and to take a new look at the way the study of foreign school systems conditioned the strategy of the political class of the time. ${ }^{74}$ Above all, it allows to validate the thesis according to which the European national school models, far from being the result of purely national policies, were born thanks to a continuous exchange of ideas and comparisons with foreign models. ${ }^{75}$ Relying on the impetus of the 'transnational turn', we should try to question the history of education in Europe with new eyes, revisiting some national myths and proposing a

69 Cf. Gerbod 1979, pp. $19 \mathrm{ff}$.

70 Topalov 1999.

71 Nóvoa/Yariv-Mashal 2003, p. 424.

72 Rosenberg 2012.

73 See Ringer 2003.

74 See communication of prof. Chiosso.

75 See Thiesse 1999. 
global reflection on the characteristics (in partly common) from which the modern European school systems of the nineteenth century have took shape.

\section{Sources and Literature}

\section{Published Sources}

1861: Codice dell'istruzione secondaria classica e tecnica e della primaria e normale. Raccolta delle leggi, regolamenti, istruzioni ed altri provvedimenti governativi emanati in base alla legge 13 novembre 1859 con note spiegative e raffronti colle leggi preesistenti, approvata dal Ministero della Pubblica Istruzione. Torino.

1865: Sulle condizioni della pubblica istruzione nel Regno d'Italia. Relazione generale presentata al Ministro dal Consiglio Superiore di Torino. Milano.

1868: Schools Inquiry Commission, I: Report of the Commissioners, presented to both Houses of Parliament by Command of Her Majesty. London.

1869: Senato del Regno. Sessione 1867. Relazione della Commissione composta dai Senatori Matteucci, Amari, Brioschi, Cibrario, Lambruschini, Sagredo e Mamiani sul progetto di legge per l'insegnamento secondario (N. 27-A). Firenze.

1874: Atti del Parlamento subalpino. Sessione del 1857-1858 (VI legislatura). Roma.

1909: Ministero della pubblica istruzione. Commissione Reale per l'ordinamento degli studi secondari in Italia. Vol. 1: Relazione. Roma.

\section{Literature}

Agostini, Cesare (1860): Il Belgio e l'Olanda dal 1789 al 1852. Cenni storici. Milano.

Armytage, Walter Harry Green (1969): The German Influence on English Education. London.

Arnold, Matthew (1868): Schools and Universities on the Continent. London.

Arrivabene, Giovanni (1871): Una pagina di storia contemporanea del Belgio. Mantova.

Benedetto, Giovanni (2012): Storia della scuola e degli studi classici. In: Atene e Roma - Serie seconda 6, pp. $384-429$.

Biancardi, Giuseppe (1998): La Civiltà Cattolica sulla libertà d'insegnamento dal 1850 al 1877. In: Annali di storia moderna e contemporanea 4, pp. 122-180.

Bölling, Rainer (1983): Sozialgeschichte der deutschen Lehrer. Ein Überblick von 1800 bis zur Gegenwart. Göttingen Bonetta, Gaetano/Fioravanti Gigliola (1995) (eds.): L'istruzione classica (1860-1910). Roma.

Bonghi, Ruggiero (1888): Istruzione secondaria in Inghilterra: scuola di Harrow. Roma.

Bonghi, Ruggiero (1889): Istruzione secondaria in Inghilterra: collegio di Eton. Roma.

Bourquin, Jean - Christophe (1993): L'État et les voyageurs savants. Légitimités individuelles et volontés politiques. Les missions du ministère de l'Instruction publique (1842-1914), Doctoral thesis (not published). Université de Paris I Panthéon-Sorbonne.

Carina, Dino (1861): Sulla istruzione primaria ed industriale della Francia, dell'Inghilterra e del Belgio. Firenze.

Caron, Jean-Claude (2007): Former des élites au XIXe siècle : entre modèles nationaux et normalisation européenne (Allemagne, France, Grande-Bretagne), 1815-1914. In: Administration et Education 4, pp. 25-37.

Cerasi, Laura (1998): Per reagire alle contrarie tendenze: l'Atene e Roma e il dibattito sulla riforma degli studi classici ai primi del secolo. In: Quaderni di storia 24, pp. 123-173.

Ciampi, Gabriella/Santangeli, Claudio (eds.) (1994): Il Consiglio superiore della pubblica istruzione. 1847-1928. Roma.

De Fort, Ester (2013): I professori. In: Lacaita, Carlo G./Fugazza, Mariachiara (eds.): L'istruzione secondaria nell'Italia unita, 1861-1901. Milano, pp. 88-102.

De Groof, Jan/Glenn, Charles (2002/2003): Un difficile equilibrio. Sistemi scolastici e libertà d'insegnamento nell'Europa continentale e mediterranea. Roma.

Denicotti, Domenico (1874): L'istruzione secondaria classica in Francia, in Prussia, in Sassonia, in Austria e in Italia. In: Rivista italiana di scienze, lettere ed arti 2, pp. 508-545.

Dhondt, Pieter (2011): Un double compromis: enjeux et débats relatifs à l'enseignement universitaire en Belgique au XIX ${ }^{\mathrm{e}}$ siècle. Gand.

Donato Di Paola, Mara (2018): Enseigner les Lettres au XIXe siècle. Histoire sociale et politique comparée des professeurs de l'enseignement secondaire public en Belgique et en Italie (1850-1914), Doctoral thesis (not published). Université Libre de Bruxelles. 
Donato Di Paola, Mara (2018): Prendre exemple du modèle scolaire allemand? La réforme des humanités en Belgique à la fin du XIX e siècle dans son contexte européen (1870-1890). In: Histoire de l'éducation 149, pp. 45-75.

Errera, Alberto (1880): Studi sull'istruzione primaria, industriale, professionale e commerciale nel Belgio. Roma.

Ferri, Luigi (1875): Insegnamento pedagogico superiore in Germania, in Francia, nel Belgio e in Italia. Studio comparato. In: Palma, Luigi/Ferri, Luigi: Legislazione scolastica comparata. Firenze.

Fiorelli, Vittoria (2012): La nazione tra i banchi: il contributo della scuola alla formazione degli italiani tra Otto e Novecento. Soveria Mannelli.

Folli, Riccardo (1882): Le scuole secondarie classiche straniere e italiane: confronti, note e proposte. Milano.

Genovesi, Giovanni (1978): I professori. In: Tomasi, Tina (ed.): La scuola secondaria in Italia (1859-1977). Firenze, pp. 33-87.

Gerbod, Paul (1965): La condition universitaire en France au XIX ${ }^{\mathrm{e}}$ siècle. Paris.

Gerbod, Paul (1979): L'enseignement à l'étranger vu par les pédagogues français (1800-1914). In: Histoire de l'éducation 5, pp. 19-29.

Giarrè, Massimiliano (1872): Sulla istruzione elementare e tecnica in Baviera, Austria, Sassonia, Prussia, Belgio e Inghilterra, con alcune considerazioni sulle scuole elementari e tecniche d'Italia e singolarmente di Firenze. Firenze.

Grootaers, Dominique (ed.) (1998): Histoire de l'enseignement en Belgique. Bruxelles.

Harrigan, Patrick (2001): Church, State and Education in France from the Falloux to the Ferry Laws: A Reassessment. In: Canadian Journal of History 26, pp. 51-83.

Hippeau, Célestin (1875): L’instruction publique en Italie. Paris.

Lacaita, Carlo Giacomo (2012): Industria e cultura tecnico- scientifica nella costruzione dell'Italia Unita. In: Lacaita, Carlo Giacomo/Poggio, Pier Paolo (eds.): Scienza, tecnica e industria nei 150 anni di unità d'Italia. Milano, pp. 41-60.

Lacaita, Carlo Giacomo/Fugazza, Mariachiara (eds.) (2013): L'istruzione secondaria nell'Italia unita, 1861-1901. Milano.

La Penna, Antonio (1993): Modello tedesco e modello francese nel dibattito sull'Università italiana. In: Soldani, Simonetta/Turi, Gabriele (eds.): Fare gli italiani. Scuola e cultura nell'Italia contemporanea. Vol. 1. Bologna, pp. 171-212.

Luzzatti, Luigi (1867): Lo Stato e la Chiesa nel Belgio, con alcune applicazioni alla questione religiosa in Italia. Milano.

Macchi, Mauro (1864): Memorie: l'insegnamento in Inghilterra in relazione allo stato ed ai bisogni dell'istruzione in Italia. In: Il Politecnico 27, pp. 121-143.

Marin, Francesco (2010): Die “deutsche Minerva” in Italien. Die Rezeption eines Universitäts- und Wissenschaftsmodells 1861-1923. Köln.

Martini, Pietro (1854): Studi storico-politici sulle libertà moderne d'Europa dal 1789 al 1852. Cagliari.

Masson, Nicole (1994): L'École normale supérieure. Les chemins de la liberté. Paris.

Matasci, Damiano (2015): L'école républicaine et l'étranger. Une histoire internationale des réformes scolaires en France, 1870-1914. Lyon.

Miotti, Giovanni Andrea (1863): Della istruzione secondaria classica in Italia con cenni comparativi su quella di Francia, Olanda, Sassonia e Prussia. Torino.

Mombert, Monique (2010): Le système éducatif allemand sous le Kaiserreich: entre pluralisme et unité nationale. In: Maurer, Catherine (ed.): Les espaces de l'Allemagne au XIX ${ }^{\mathrm{e}}$ siècle. Frontières, centres et question nationale. Strasbourg, pp. 119-130.

Müller, Detlef/Ringer, Fritz/Simon, Brian (eds.) (1987): The Rise of the Modern Educational System: Structural Change and Social Reproduction 1870-1920. Cambridge/Paris.

Nóvoa, Antonio (1998): Histoire et comparaison. Lisboa.

Nóvoa, Antonio/Yariv-Mashal, Tali (2003): Comparative Research in Education: A Mode of Governance or a Historical Journey? In: Comparative Education 39, 4, pp. 423-438.

Parola, Luigi/Botta, Vincenzo (1851): Del pubblico insegnamento in Germania. Torino.

Pazzaglia, Luciano (1965): Dalla scuola del disimpegno alla scuola del dialogo: linee di sviluppo, Vita e Pensiero 10, pp. 784-799.

Petrucelli della Gattina, Ferdinando (1879): L'istruzione tecnica in Inghilterra. Roma.

Piazzi, Alfredo (1894): Scuole e Questioni pedagogiche in Germania. Roma.

Porciani, Ilaria (ed.) (1994): L'Università tra Otto e Novecento: i modelli europei e il caso italiano. Napoli.

Pullè, Francesco Lorenzo (1877): Legislazione scolastica comparata. Dell'istruzione secondaria specialmente classica in Prussia ed in Germania. In: Studi di legislazione scolastica, ed. by Ministro d'istruzione pubblica. Firenze, pp. $1-136$. 
Raicich, Marino (1981): Le polemiche sugli studi classici intorno al 1870 e l'Inchiesta Scialoia. In: Id. (ed.): Scuola, cultura e politica da De Sanctis a Gentile. Pisa, pp. 285-325.

Ringer, Fritz (2003): La segmentation des systèmes d'enseignement. La réforme de l'enseignement secondaire français et prussien, 1865-1920. In: Actes de la recherche en sciences sociales 149, pp. 6-20.

Rosenberg, Emily (ed.) (2012): A World Connecting, 1870-1945. Cambridge.

Rossi, Egisto (1889): La istruzione pubblica negli Stati Uniti. Roma.

Santoni Rugiu, Antonio/Santamaita, Saverio (2011): Il professore nella scuola italiana dall'Ottocento a oggi. RomaBari.

Scavia, Giovanni (1866): Dell'istruzione professionale e secondaria femminile in Francia, Germania, Svizzera e Italia. Torino.

Scopoli, Giovanni (1879): Dell'istruzione nelle belle lettere (i ginnasi), frammento dell'opera inedita intitolata "relazione della visita delle pubbliche scuole in più luoghi di Germania e riflessioni su quelle del Regno”. Verona.

Talamanca, Anna (1975): Libertà della scuola e libertà nella scuola. Padova.

Talamo, Giuseppe (1960): La scuola dalla legge Casati alla inchiesta del 1864. Milano.

Targhetta, Fabio (2010): “Uno sguardo all'Europa”. Modelli scolastici, viaggi pedagogici ed importazioni didattiche nei primi cinquant'anni di scuola italiana. In: Chiaranda, Mirella (ed.): Storia comparata dell'educazione. Problemi ed esperienze tra Otto e Novecento. Milano, pp. 155-176.

Thiesse, Anne-Marie (1999): La création des identités nationales. Europe XVIII ${ }^{e}-X^{e}$ siècle. Paris.

Topalov, Christian (ed.) (1999): Laboratoires du nouveau siècle. La nébuleuse réformatrice et ses réseaux en France 1880-1914. Paris.

Valentini, Gilberto (1959): Prussia e Francia, modelli stranieri della legge Casati del 1859. In: I problemi della pedagogia 5, pp. 228-243.

Villari, Pasquale (1868): Scritti pedagogici. Firenze [etc.].

Zymek, Bernd (1975): Das Ausland als Argument in der pädagogischen Reformdiskussion. Ratingen. 